Creative Commons User License: CC BY-NC-ND

Abstracted by: EBSCOhost, Electronic Journals Service (EJS),

Google Scholar, Journal Seek, Scientific Commons,

Food and Agricultural Organization (FAO), CABI and Scopus
Journal of Agricultural Extension

Vol. 24 (4) October, 2020

ISSN(e): 24086851; ISSN(Print); 1119944X

http://journal.aesonnigeria.org

http://www.ajol.info/index.php/iae

Email: editorinchief@aesonnigeria.org

http://eoi.citefactor.org/10.11226/v24i4

\title{
Effects of the Psaltry Cassava Out-grower Scheme in Enhancing Smallholder Productivity in Oke-Ogun Area of Oyo State, Nigeria
}

https://dx.doi.org/10.4314/jae.v24i4.14

\author{
Olushola Fadairo \\ Department of Agricultural Extension and Rural Development, University of Ibadan, Nigeria. \\ Email: dairom2@gmail.com \\ Phone: +2347030184660
}

\section{Oladimeji Alarape}

Centre for Sustainable Development, University of Ibadan, Nigeria.

Email: oladimejialarapet@gmail.com

Phone: +2347033221164

\section{Abstract}

This study assessed the effects of Psaltry cassava Out-grower scheme in enhancing smallholder productivity in Oke-Ogun area of Oyo State. Pre- and post-intervention combined with treatment and control group designs were used. Data were collected from 232 Out-grower and 49 non- Out-grower farmers using interview schedules. Data were analysed using percentages, $t$ test and regression analysis. Assured markets (90.5\%) and training on postharvest handling of crops (69.9\%) were the most common supports received from Psaltry. Long bureaucracy involved in documentation $(\bar{x}=2.23)$ was the most severe constraint faced in the scheme. Total cassava harvested and productivity among Out-growers increased from $30,950.89 \pm 31,133.48 \mathrm{~kg}$ to $106,116.88 \pm 96,926.01 \mathrm{~kg}$ and $5,649.2 \pm 3835.3 \mathrm{~kg} /$ Acre to $9,143.6 \pm 8799.1$ $\mathrm{kg} /$ Acre before and after participating in Psaltry scheme, respectively. A significant difference existed between the productivity of Out-growers and non- Out-growers ( $t=7.256 ; p \leq 0.05)$. Membership of group $(\beta=0.319)$ and length of involvement in the Psaltry scheme $(\beta=0.157)$ positively and significantly influenced Out-growers' cassava productivity. The Psaltry Outgrower scheme had stimulated beneficiary's smallholder farmers towards higher productivity. A scale-up of the Psaltry model has prospects for transforming smallholder farmers to commercial producers.

Keywords: Out-grower scheme, cassava farmers, market linkage, smallholder farmers, psaltry scheme.

\section{Introduction}

The cassava farming industry is a very large industry that thrives in countries such as Nigeria, Thailand, Brazil, Indonesia and Republic of the Congo (Shackelford, Haddaway, Usieta, Pypers, Petrovan and Sutherland, 2018). In 2014, global production of cassava root was 268 million tones, with Nigeria as the world's largest producer of nearly 55 million tones or 21 percent of the world total cassava-farming (Ohimain, 2015; Ogunyinka, Guwelamgomba, Kaitira, Oguntuase, Otim and Otim, 2018). The growth in cassava production has been primarily due to rapid population growth, large internal market demand, complemented by the availability of high yielding improved varieties, a relatively well-developed market access infrastructure, the existence of improved processing technology and a well-organized internal 
Creative Commons User License: CC BY-NC-ND

Abstracted by: EBSCOhost, Electronic Journals Service (EJS),

Google Scholar, Journal Seek, Scientific Commons,

Food and Agricultural Organization (FAO), CABI and Scopus
Journal of Agricultural Extension

Vol. 24 (4) October, 2020

ISSN(e): 24086851; ISSN(Print); 1119944X

http://journal.aesonnigeria.org

http://www.ajol.info/index.php/iae

Email: editorinchief@aesonnigeria.org

market structure (Forsythe, Posthumus and Martin, 2016). Cassava has high poverty-reduction potential thus has long been used as a famine reserve and food security crop. This is because of its low production cost, widespread cultivation, and job creation capacity, especially for women and rural youth (Saediman, Aisa, Zani, Limi and Yusria, 2019; Adebayo and Silberberger, 2020).

While it is true that Nigeria is the largest cassava producing country in the world, agro-industries are still unable to obtain adequate and reliable cassava supplies due to the dominance of subsistence production systems (Rahman and Awerije, 2015, Adewuyi, 2020). Hence, production is not oriented towards commercialization instead, farmers produce and process cassava at a subsistence level. Therefore, cassava processors often face problems in sourcing adequate quantity and appropriate quality roots for processing resulting in inadequate processing capacity that lowers net profit potential for processors (Agwu, Njom and Umeh, 2017; Abong, Shibairo, Wanjekeche, Ogendo, Wambua and Lamuka, 2016). Other challenges associated with cassava production in Nigeria include low input use, rudimentary technology, large post-harvest losses, poor extension coverage and limited processing options. Most rural development efforts in Western and Central Africa that focused mainly on improving farmers' yields did not translate into increased farmers' income. Therefore, as the production of cassava is growing, the role of an efficient market and a better-coordinated cassava value chain is becoming increasingly important to producers and processors who depend on a stable cassava enterprise for income (Lamboll, Nelson, Posthumus, Martin, Adebayo, Alacho and Abayomi, 2015).

In the Nigerian open market, cassava is known to be a commodity that follows a cyclic trend of glut and scarcity usually within an interval of three years (Otekunrin and Sawicka, 2019). As such, farmers who produce without getting a stable market to sell need to be appropriately connected with users who often face cassava scarcity either as industrial raw material or as a source of household staple food. The need to bridge this critical gap in the cassava sub-sector prompted the interventions of various Out-grower's companies in the sub-sector. One of such Out-grower companies is the Psaltery firm which is domiciled in the Oke-Ogun region of Oyo State, Nigeria. Psaltry International Company Limited (PIL) is an agro-allied company founded in 2005. According to Anudu and Faminu (2019), the company came into existence as a result of the drive for local input sourcing for manufacturing sector by its proprietor. The company operates a nucleus farm with Out-growers and a cassava agro-processing facility that produces high quality cassava starch. Other cassava-based pproducts manufactured by PIL are high quality flour (gluten free), Sorbitol and Glucose. Notable biggest buyers of PIL products in Nigeria are Nigerian Breweries, Nestle Nigeria Plc and Yale Foods, Ibadan. (PIL, 2015). The PIL provides support services including training, extension, and market linkage to its farmers.

In 2012, PIL initiated an out-grower program for farmers within $80 \mathrm{~km}$ radius to its factory located in Iseyin area of Oyo State. This initiative followed an increased demand for cassava bye-products by pharmaceutical and confectionery companies. The PIL out-grower model deliberately targets smallholder suppliers and offering them higher prices to encourage subsistence farmers to expand and commercialize 
Creative Commons User License: CC BY-NC-ND

Abstracted by: EBSCOhost, Electronic Journals Service (EJS),

Google Scholar, Journal Seek, Scientific Commons,

Food and Agricultural Organization (FAO), CABI and Scopus
Journal of Agricultural Extension

Vol. 24 (4) October, 2020

ISSN(e): 24086851; ISSN(Print); 1119944X

http://journal.aesonnigeria.org

http://www.ajol.info/index.php/jae

Email: editorinchief@aesonnigeria.org

their cassava production (Spore Magazine, 2017). The company provides support services including training, extension, and market linkage to its farmers. The company also provide a buy-back arrangement for its registered Out-grower farmers and non-registered farmers as well (Anudu and Faminu, 2019). Currently, Psaltry sources its cassava from groups of smallholder farmers involving an estimated 5,000 farm families which include more than 2,000 registered and unregistered out-grower farm families (Spore Magazine, 2017; Anudu and Faminu, 2019). This study therefore ascertained the effects of Psaltry cassava out-grower scheme in enhancing smallholder productivity in the Oke-Ogun area of Oyo State, Nigeria. Specifically, the study investigated the socio-economic characteristics of the Psaltery out-grower cassava farmers, supports received from Psaltry, their change in cassava productivity due to participation in the Psaltry scheme and challenges faced in participating in the scheme.

\section{Psaltery Out-grower Model}

Figure 1 shows the conceptual model of Psaltry operation. Out-grower farmers are usually recruited with assistance from the extension officers who also broker the contractual agreement process between the company and the farmers. Sealing the contractual arrangements involved signing of memorandum of understanding, submission of dully completed biodata and guarantor forms. Farmers are categorised into three groups ( $A, B$ and $C$ ) based on years of participation in the Psaltry Out-grower scheme. This categorisation has implication for the kinds of support received by farmers from the scheme. The grade $C$ farmers are beginners who occupy the base of the Out-growers pyramid. They only benefit from stable market, improved cassava stem and provision of land/training on agribusiness. The grade B farmers comprise Out-growers with up to two years commitment in the scheme. They have access to training on good agricultural practices, access to agrisupport services, post-harvest handling and tractor for ploughing in addition to all benefits received by beginners. Farmers in grade A occupies the top of the pyramid haven shown up to five years' commitment to the scheme. They have access to fertilizers, agrochemicals, extension services, and credit support/linkage in addition to all the benefits received by grades B and C Out-growers. Through a buy-back arrangement, harvested cassava produce are bought by the PIL from the Out-grower at an agreed rate after each production cycle is completed. The process is expected to translate to higher efficiency of production and enhanced income for the Outgrowers. At the end of each cycle, Out-growers are free to decide to continue with the scheme or not. 


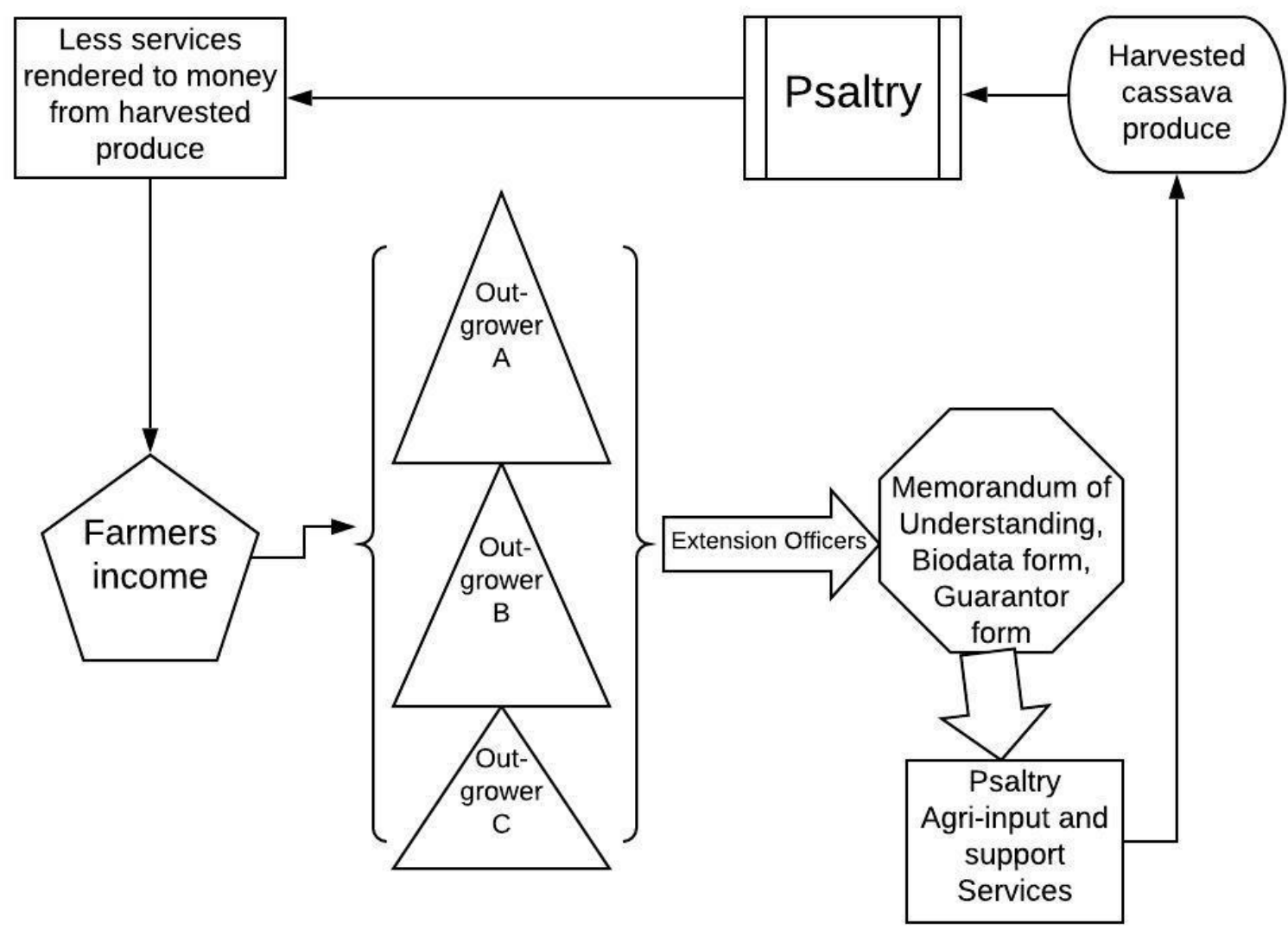

\section{Figure 1: Conceptual model of Psaltry Out-grower scheme}

\section{Methodology}

The research was conducted in Oke-Ogun region of Oyo State, on longitude $3020^{\prime} \mathrm{E}$ and latitude $8040^{\prime} \mathrm{N}$, with mean elevation of $400 \mathrm{~m}$ above sea level (Fadairo, Williams and Nalwanga, 2019). The region comprises of ten out of the 33 local governments areas that make up Oyo State. Quasi-experimental research design involving participants and non-participants' assessment was used for the study.

Data were collected using interview schedules from 281 smallholder cassava farmers comprising 232 Psaltry Out-growers and 49 non- Out-growers. The Psaltry Out-growers were sampled using multi-stage sampling procedure. The first stage involved a purposive selection of the five local government areas (Iseyin, Ibarapa, Kajola, Itesiwaju and Saki) where the Psaltry project is implemented in the region. For administrative purposes, Psaltry Out-grower farmers in these areas are organized in eight clusters namely; Alayide-Wasimi, Ado-Awaye, Ikere, Iseyin, Lanlate, Tede, Okaka/Otu, and Oke-ogun. In the second stage, a list of Out-grower farmers in each of the clusters were obtained from the Psaltry agribusiness manager. Simple random sampling technique was used to select $30 \%$ of the participating farmers in each cluster to give 232 Out-grower farmers across the clusters. The Psaltry scheme operates and provides extension services and benefits 
Creative Commons User License: CC BY-NC-ND

Abstracted by: EBSCOhost, Electronic Journals Service (EJS),

Google Scholar, Journal Seek, Scientific Commons,

Food and Agricultural Organization (FAO), CABI and Scopus
Journal of Agricultural Extension

Vol. 24 (4) October, 2020

ISSN(e): 24086851; ISSN(Print); 1119944X

http://journal.aesonnigeria.org

http://www.ajol.info/index.php/jae

Email: editorinchief@aesonnigeria.org

only to its Out-grower farmers, but also provides an avenue for non- Out-grower farmers in the study area to sell cassava tubers to the Psaltry organization. A total of 49 non- Out-growers who came to sell their cassava produce to Psaltry were identified and also sampled. Only those who were spotted at the sales point and who were also willing to participate in the study were sampled.

The respondents' stated their actual farming experience and years of involvement in the Psaltry scheme. Out-growers access to agri-support services and inputs were measured by providing them with a list of support items provided by the Psaltry scheme. They were asked to tick which of the items they had access to before and after involving in the scheme. The difference in the proportion of respondents who had access to each of the support items before and after Psaltery was used to rank the items in order of coverage among respondents. Influence of Psaltry scheme on cassava productivity was measured in terms of changes in size of land cultivated (acres) and cassava production (measured in Kilogram) before and after involvement in the Psaltry scheme. Productivity was thus estimated using the formula total output of cassava divided by total land area cultivated. A comparison of the mean productivity score of the Psaltry Out-grower farmers before and after involvement in the scheme; and the mean productivity of Out-growers and non-Out-growers were used to draw inferences on the influence of the Psaltry scheme on cassava productivity. Challenges/constraints faced in Psaltry scheme were determined by asking each respondent to mention their challenges in an open-ended manner and afterward ranking them as severe (2) or mild (1). Mean values for each of the challenges were determined and used to rank them in order of severity. Descriptive data were analysed and summarized using frequency counts, percentages, mean and rank. Linear regression was used to determine the factors influencing Psaltry Out-grower farmers' productivity at $95 \%$ level of significance.

\section{Results and Discussion}

\section{Respondents' Socio-economic Characteristics}

Table 1 shows that most of the cassava farmers possessed their farmlands mainly through inheritance ( $>50 \%)$. This finding aligns with several positions in literature that suggests the dominance of male in primary agricultural production in Africa (Wekesah, Mutua and Izugbara, 2019) and the poor level of literacy among most smallholder farmers (Abdul-Razak and Kruse, 2017). On the average, the non- Outgrowers had longer been involved in cassava farming (6.26 \pm 2.3 years) than the

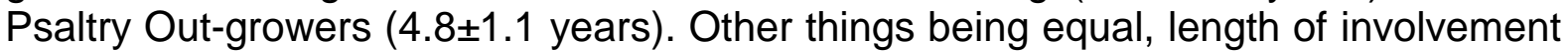
in the enterprise should influence experience and practices, hence, yield and profitability. This finding also suggests that the Psaltry Out-grower scheme was more attractive to newer cassava farmers in the study area. This is possibly due to the numerous incentives offered by the scheme which may be more required by new entrants into the enterprise in order to gain quick stability for the competitive market. In terms of other enterprises involved by the respondents, the table shows that an overwhelming proportion of the Out-growers (89.7\%) and non- Out-growers $(95.9 \%)$ were involved in other arable crop farming in addition to cassava. This implies that 
Creative Commons User License: CC BY-NC-ND

Abstracted by: EBSCOhost, Electronic Journals Service (EJS), Google Scholar, Journal Seek, Scientific Commons,

Food and Agricultural Organization (FAO), CABI and Scopus
Journal of Agricultural Extension

Vol. 24 (4) October, 2020

ISSN(e): 24086851; ISSN(Print); 1119944X

http://journal.aesonnigeria.org

http://www.ajol.info/index.php/iae

Email: editorinchief@aesonnigeria.org

the farmers were involved in mixed cropping. Mixed cropping is encouraged among smallholder farmers in the wake of increasing climate uncertainties in order to minimize loss due to crop failure (Azumah, Donkoh and Ansah, 2017). Furthermore, apart from crop farming, respondents also engaged in other livelihood activities such as petty trading, and livestock rearing. Also, majority of the Out-grower farmers $(63.3 \%)$ have been involved in the Psaltry scheme for 2 years and above.

Table 1: Respondents socio-economic characteristics

\begin{tabular}{llc}
\hline Variables & Psaltry Out-growers & Non- Out-growers \\
\cline { 2 - 3 } Membership of farmers group & $\%$ & $\%$ \\
\cline { 2 - 3 } Yes & 96.1 & 100 \\
Source of farmland & & \\
Self-owned & 9.9 & 30.6 \\
Inherited & 58.2 & 51.0 \\
Leased/borrowed & 31.5 & 18.4 \\
Years in cassava farming & & \\
$<2$ & 41.4 & 2.0 \\
$3-5$ & 53.4 & 55.1 \\
$6-8$ & 4.3 & 24.5 \\
$>8$ & 9 & 18.4 \\
Mean & $4.8 \pm 1.1$ & $6.3 \pm 2.3$ \\
Agricultural enterprises & & \\
Arable crops other than cassava & 89.7 & 95.9 \\
Livestock rearing & 44.4 & 36.7 \\
Fishing & 9.1 & 6.1 \\
Hunting & 6.5 & 30.6 \\
Processing of farm produce & 39.2 & 51.0 \\
Petty trading & 44.4 & 59.2 \\
Involvement in Psaltery (years) & & 0 \\
<2 & 36.7 & 0 \\
2-3 & 58.6 & 0 \\
$>3$ & 4.7 & 0.0 \\
Mean & $2.8 \pm 1.1$ &
\end{tabular}

${ }^{*}$ Multiple responses

\section{Access to Agri-Support Services and Inputs by Psaltry Out-Grower Farmers}

Table 2 shows the percent change in the proportion of Out-grower farmers that had access to agri-inputs and support services for cassava production since their participation in the Psaltry scheme. More proportion of the respondents had access to all the agri-inputs and support services after joining the Psaltry scheme suggesting that the scheme had actually touched on all major aspects of support services needed for cassava production in the areas. It can also be inferred that none of the participating farmers was excluded from the coverage of these benefits. After joining the scheme, majority of the respondents had access to stable market for their produce $(91.0 \%)$, tractor for ploughing $(74 \%)$, pesticides/herbicides $(73.3 \%)$, 
Creative Commons User License: CC BY-NC-ND

Abstracted by: EBSCOhost, Electronic Journals Service (EJS),

Google Scholar, Journal Seek, Scientific Commons,

Food and Agricultural Organization (FAO), CABI and Scopus
Journal of Agricultural Extension

Vol. 24 (4) October, 2020

ISSN(e): 24086851; ISSN(Print); 1119944X

http://journal.aesonnigeria.org

http://www.ajol.info/index.php/jae

Email: editorinchief@aesonnigeria.org

extension services (65.0\%) and fertilizers (63.0\%). In terms of changes in the proportion of farmers who had access to agri-inputs and support services before and after joining the Psaltry scheme, changes were mostly pronounced in the areas of assured market for cassava tubers (81\%), credit support (49\%), post-harvest handling services $(48.3 \%)$ and pricing for cassava tubers $(44.3 \%)$. On the other hand, marginal changes were observed in terms of fertilizer supply (6.0\%), access to pesticides/herbicides (12.1\%), access to tractors for land preparation (14.1\%) and training on good agricultural practices which covers land preparation, plant spacing and others (15.3\%). The distribution suggests degree of emphasis placed on the various production support items by the Psaltry Out-grower scheme and possibly, the motivating factors for Psaltry Out-grower farmers. The reason for this is not farfetched as markets, pricing and post-harvest storage of tubers have been identified as critical problems confronting growth in cassava industry in Nigeria due to its intermittent cycle of glut and scarcity (Ferraro, Piccirillo, Tomlins and Pintado, 2016).

\section{Table 2: Access to Agri-support services and inputs by Psaltry out-grower} farmers

\begin{tabular}{llll}
\hline Agri-support services and inputs & $\begin{array}{l}\text { Before } \\
\text { Psaltry (\%) }\end{array}$ & $\begin{array}{l}\text { During } \\
\text { Psaltry } \\
\text { (\%) }\end{array}$ & $\begin{array}{l}\text { Changes in the } \\
\text { proportion of } \\
\text { farmers who } \\
\text { had access } \\
\text { before and } \\
\text { after joining } \\
\text { Psaltry (\%) }\end{array}$ \\
\hline Training on good agricultural practices & 45.3 & 60.3 & 15.0 \\
Post-harvest handling & 11.2 & 60.0 & 48.8 \\
Training on agribusiness & 45.3 & 60.8 & 15.5 \\
Financial literacy & 20.3 & 60.0 & 39.7 \\
Agricultural extension services & 38.0 & 65.0 & 27.0 \\
Credit support or linkage & 10.0 & 59.0 & 49.0 \\
Access to agri-support services & 17.2 & 60.3 & 43.1 \\
Improved cassava stream & 38.0 & 62.1 & 24.1 \\
Fertilizers & 57.0 & 63.0 & 6.0 \\
Pesticides/herbicides & 61.2 & 73.3 & 12.1 \\
Tractor for ploughing & 59.9 & 74.0 & 14.1 \\
Stable market for cassava harvested & 10.0 & 91.0 & 81.0 \\
Better price offer for cassava & 10.0 & 54.3 & 44.3 \\
Others & 10.3 & 39.2 & 28.9 \\
\hline
\end{tabular}

Influence of the Psaltry Out-Grower Scheme on Cassava Productivity

Table 3a shows the performance of the Psaltry Out-growers scheme in terms of land size cultivated, total harvest and productivity before and after participating in the Psaltry scheme. Psaltry Out-grower farmers' land area cultivated increased from 5.84 acres to 12.4 acres before and after participating in the scheme, respectively, showing a mean improvement of about 6.6 acres. Similarly, average tuber harvested increased from $30,950.9 \mathrm{~kg}$ before Psaltry to $106,116.9 \mathrm{~kg}$ after Psaltry, representing $75,166 \mathrm{~kg}$ difference on the average. Also, productivity rose from 5,649.2 kg/acre to 
Creative Commons User License: CC BY-NC-ND

Abstracted by: EBSCOhost, Electronic Journals Service (EJS),

Google Scholar, Journal Seek, Scientific Commons,

Food and Agricultural Organization (FAO), CABI and Scopus
Journal of Agricultural Extension

Vol. 24 (4) October, 2020

ISSN(e): 24086851; ISSN(Print); 1119944X

http://journal.aesonnigeria.org

http://www.ajol.info/index.php/jae

Email: editorinchief@aesonnigeria.org

9,143.6 $\mathrm{kg} / \mathrm{acre}$ before and after participating in the scheme, respectively. Furthermore, Table 3 (b) shows a comparison between the Psaltry Out-grower and the non-Out-grower farmers. In terms of total cassava harvested, the Out-grower farmers recorded a mean total of $106,116.9 \mathrm{~kg}$, while non- Out-grower farmers recorded $79,408.16 \mathrm{~kg}$. In the same vein, while the average productivity recorded by the Out-grower farmers was 9,143.6 kg/acre, the non- Out-growers attained a productivity of $1,047.2 \mathrm{~kg} /$ acre representing a difference of about $8,100 \mathrm{~kg}$ above their non-Psaltery counterparts. The foregoing shows an improvement in the average land size cultivated, quantity of tuber harvested and yield of cassava among the Psaltry Out-grower farmers. It thus suggests that the Psaltry Out-grower scheme has been able to influence farmers decision to increase their factors of production for cassava enterprise.

Given the vast availability of cultivable land in Nigeria, agricultural extensification approach is quite popular for boosting production (Fadairo Olajuyigbe, Osayomi, Adelakun, Olaniyan, Olutegbe and Adeleke, 2020). Achieving optimum yield and higher efficiency in production process however necessitates that agricultural intensification approach be synchronised side by side with extensification (Zabel, Delzeit, Schneider, Seppelt, Mauser and Václavík, 2019). This means that as farmers are motivated to increase land size cultivated for cassava, they should also be guided towards achieving optimum yield per unit area cultivated. Hence, the Psaltry initiative can be said to be on the right path towards improving Nigeria's selfsufficiency ratio in terms of cassava production.

Table 3(a): Psaltry out-grower farmers' enterprise scale and productivity before and after the scheme

\begin{tabular}{lll}
\hline Variables & Out-growers & Mean \pm SD \\
\hline \multirow{2}{*}{ Land cultivated (Acres) } & Before Psaltry & $5.84 \pm 4.1$ \\
& After Psaltry & $12.4 \pm 5.89$ \\
Total cassava harvest $(\mathrm{kg})$ & Before Psaltry & $30,950.9 \pm 31,133.5$ \\
Productivity (Kg/Acre) & After Psaltry & $106,116.9 \pm 96,926.01$ \\
& Before Psaltry & $5,649.2 \pm 3,835.3$ \\
& After Psaltry & $9,143.6 \pm 8,799.1$ \\
\hline
\end{tabular}

Table 3(b): Psaltry Out-grower and non- Out-grower farmers productivity

\begin{tabular}{lll}
\hline Variables & Farmers category & Mean \pm SD \\
\hline Land cultivated (Acres) & Out-growers & $12.4 \pm 5.89$ \\
& Non- out-growers & $10.9 \pm 25.80$ \\
Total cassava harvest $(\mathrm{kg})$ & Out-growers & $106,116.9 \pm 96,926.01$ \\
& Non- Out-growers & $79,408.2 \pm 84,996.79$ \\
Productivity (Kg/Acre) & Out-growers & $9,143.6 \pm 8,799.1$ \\
& Non- out-growers & $1,047.2 \pm 4,789.34$ \\
\hline
\end{tabular}

\section{Challenges in the Psaltry Out-grower Scheme}

Figure 2 shows that long bureaucratic process involved in documentation for the Psaltry scheme $(2.23 \pm 0.7)$, too technical and unclear information $(1.83 \pm 0.4)$ and too 
Creative Commons User License: CC BY-NC-ND

Abstracted by: EBSCOhost, Electronic Journals Service (EJS), Google Scholar, Journal Seek, Scientific Commons,

Food and Agricultural Organization (FAO), CABI and Scopus
Journal of Agricultural Extension

Vol. 24 (4) October, 2020

ISSN(e): 24086851; ISSN(Print); 1119944X

http://journal.aesonnigeria.org

http://www.ajol.info/index.php/jae

Email: editorinchief@aesonnigeria.org

frequent visit/meetings $(1.51 \pm 0.5)$ were the more prominent challenges considered as being faced by the farmers in the Psaltry scheme. Other challenges such as renege on promises and pricing complexity were not severe among an overwhelming proportion of the respondents. The low level of education among the farmers (Table 1) could be a possible factor underpinning poor clarity of information received and boredom faced from the bureaucratic procedures in the Psaltry scheme. The Psaltry Out-grower scheme officials working with the farmers may need to evolve a more effective communication approaches with careful attention to the farmers' level of literacy for improved effectiveness. Previous studies showed that stiff bureaucracy in organisations can lead to boredom among clienteles with low levels of education due to too much of technical information associated with the process (Bryson, 2018; Schauer, 2015).

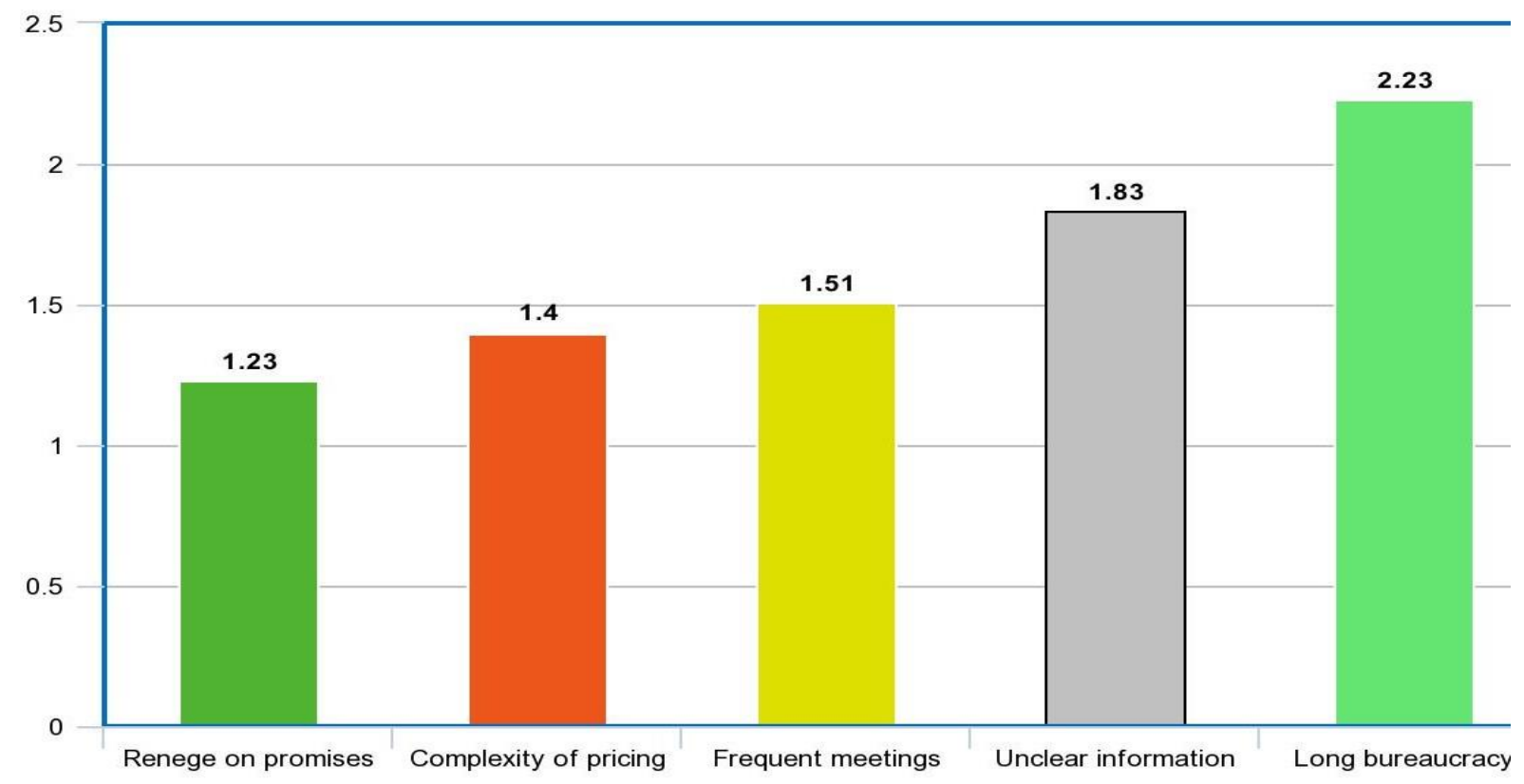

Figure 2: Constraints faced in Psaltery scheme by Out-grower farmers

\section{Difference in the Psaltry Out-grower and Non- Out-Grower Farmers' Productivity}

Table 5 shows a significant difference between the cassava productivity of Outgrower and non- Out-grower farmers $(t=7.256 ; p \leq 0.05)$ with higher mean productivity in favour of the Psaltry Out-growers. This results therefore establishes that a clear difference exists in the productivity of the two groups of farmers. Given the close similarities between these two groups of farmers as revealed in Table 1, it is not farfetched to infer that the observed difference in terms of cassava productivity between the two categories of cassava farmers has been influenced by the Psaltry scheme. Studies on effectiveness of regional and local development interventions on cassava production revealed that most of the programmes were effective in achieving their goals (Tafon and Saunders, 2015; Ogunyinka et al, 2018). The outcome from this 
Creative Commons User License: CC BY-NC-ND

Abstracted by: EBSCOhost, Electronic Journals Service (EJS),

Google Scholar, Journal Seek, Scientific Commons,

Food and Agricultural Organization (FAO), CABI and Scopus
Journal of Agricultural Extension

Vol. 24 (4) October, 2020

ISSN(e): 24086851; ISSN(Print); 1119944X

http://journal.aesonnigeria.org

http://www.ajol.info/index.php/iae

Email: editorinchief@aesonnigeria.org

independent evaluation of the Psaltry scheme suggests that the scheme is fairly keeping up with its projections of improving Out-growers cassava productivity from the baseline average of $9.5 \mathrm{MT} /$ year to $28 \mathrm{MT} /$ ha in five years with up to $350 \%$ increase in their net income (Van der Velden, Isenberg, Ugwu, Hanssens, Saab and Speelman, 2018).

Table 5: Test of difference in cassava productivity between Psaltry Out-grower and non- out-grower farmers.

\begin{tabular}{lrcrl}
\hline & Mean & $\begin{array}{c}\text { Mean } \\
\text { difference }\end{array}$ & df & t-value \\
\hline Out-grower farmers & 9143.619 & 9133.4760 & 278 & $7.256^{\star}$ \\
$\begin{array}{l}\text { Non- Out-grower } \\
\text { farmers }\end{array}$ & 10.1439 & & & \\
${ }^{\star} \mathrm{p} \leq 0.05$ & & & &
\end{tabular}

\section{Factors Influencing Productivity of Psaltery Out-grower Farmers}

Table 6 shows the influence of selected independent variables on productivity of farmers under the Psaltry Out-grower scheme. The result shows that constraints faced by the respondents $(\beta=-.295, p<0.05)$, membership of farmers group $(\beta=0.319, \quad p<0.05)$ and length of involvement in Psaltry $(\beta=0.157, p<0.05)$ significantly influenced respondents' productivity after participating in Psaltry Outgrower scheme. Only $18 \%$ of the variation in farmers change in productivity is accounted for by the explanatory variables tested in this study. Length of involvement in the Psaltry scheme might influence productivity due to the fact that differences exists in the benefits received from the scheme by the Out-grower farmers depending on their years of commitment. Farmers with commitment of five years and above in the scheme are priority Out-growers who enjoys limitless support from the scheme. Also, farmers who associate with more experienced Out-growers may be at an advantage of accessing relevant information through peer-interaction and learning process. Several studies have emphasised the importance of group membership for peer-learning and innovation diffusion (Wuepper, Sauer and Kleemann, 2018; Worku, 2019). Also, the positive influence of length of participation in the Psaltry scheme on farmers productivity is consistent with the argument that increased participation or involvement in any enterprise leads to more experience and better outcomes for any individual or group (Dong, Sivakumar, Evans and Zou, 2015; Worku, 2019). The negative correlation of constraints with change in productivity of the Out-growers suggests that the more severe the farmers constraints became, the more reduced their productivity was. It an indication that the aforementioned challenges (Figure 2) associated with the scheme affects their productivity to a reasonable extent and should therefore be looked into in order to improve the scheme's efficiency. Similar challenges of bureaucratic procedures as identified in this study, have been adduced as the bane of a number of development interventions (Sibanda, 2019), including agricultural credits schemes for farmers (Dhakshana and Rajandran, 2018). 
Creative Commons User License: CC BY-NC-ND

Abstracted by: EBSCOhost, Electronic Journals Service (EJS),

Google Scholar, Journal Seek, Scientific Commons,

Food and Agricultural Organization (FAO), CABI and Scopus

http://eoi.citefactor.org/10.11226/v24i4
Journal of Agricultural Extension

Vol. 24 (4) October, 2020

ISSN(e): 24086851; ISSN(Print); 1119944X

http://journal.aesonnigeria.org

http://www.ajol.info/index.php/iae

Email: editorinchief@aesonnigeria.org

Table 6: Factors influencing changes in productivity of the Psaltery Outgrower cassava farmers

$(\beta)$

t-value

(Constant)

Perception

Constraints

Benefits derived

Age

Sex

Education

Membership of farmers group

Length of involvement in Psaltry

How often do you receive extension

${ }^{*} \mathrm{p} \leq 0.05 ; \mathrm{R}=0.464 ; \mathrm{R}^{2}=0.215 ;$ Adjusted $\mathrm{R}^{2}=0.183 ;$ Standard error $=5614.70$
$-0.244$

1.069

$-4.532^{\star}$

$-1.079$

0.245

0.483

0.723

$\begin{array}{ll}0.051 & 0.723 \\ 0.319 & 5.047^{\star}\end{array}$

$0.157 \quad 2.21^{*}$

$0.012 \quad 0.184$

\section{Conclusion and Recommendations}

Psaltry Out-grower scheme had stimulated smallholder farmers towards enterprise scale expansion and higher productivity. The scheme's inclusive model and compliance with the promised agri-input and support services has particularly attracted many young and new entrant farmers into the cassava industry. A scale-up of the Psaltry model has prospects for transforming smallholder farmers to commercial producers. In addition, given that farmers with longer period of commitment in the scheme were the most productive, mechanisms to sustain continued interests of individual farmers in the scheme for a sufficient period of at least three consecutive years will pay off for both the farmer and the out-grower company.

\section{References}

Abdul-Razak, M., and Kruse, S. (2017). The adaptive capacity of smallholder farmers to climate change in the Northern Region of Ghana. Climate Risk Management, 17, 104-122.

Abong, G. O., Shibairo, S., Wanjekeche, E., Ogendo, J., Wambua, T., and Lamuka, P. (2016). Post-harvest practices, constraints and opportunities along cassava value chain in Kenya. Current Research in Nutrition and Food Science, 4(2), 114-126.

Adebayo, W. G., and Silberberger, M. (2020). Poverty reduction, sustainable agricultural development, and the cassava value chain in Nigeria. In the Palgrave Handbook of Agricultural and Rural Development in Africa (pp. 525-551). Palgrave Macmillan, Cham.

Adewuyi, A. (2020). Challenges and prospects of renewable energy in Nigeria: A case of bioethanol and biodiesel production. Energy Reports, 6, 77-88. 
Creative Commons User License: CC BY-NC-ND

Abstracted by: EBSCOhost, Electronic Journals Service (EJS),

Google Scholar, Journal Seek, Scientific Commons,

Food and Agricultural Organization (FAO), CABI and Scopus
Journal of Agricultural Extension

Vol. 24 (4) October, 2020

ISSN(e): 24086851; ISSN(Print); 1119944X

http://journal.aesonnigeria.org

http://www.ajol.info/index.php/iae

Email: editorinchief@aesonnigeria.org

http://eoi.citefactor.org/10.11226/v24i4

Agwu, A. E., Njom, P. C., and Umeh, B. U. (2017). Farmers adoption scenarios for the control of cassava mosaic disease under the Cassava Enterprise Development Project in Enugu State, Nigeria. Journal of Agricultural Extension, 21(1), 181-197.

Anudu, O. and Faminu, G. (2019). In the drive for local input sourcing in manufacturing sector. Business Day Newspaper, May 16, 2019. Available at: https://businessday.ng/business-economy/article/the-drive-for-local-input-sourcing-inmanufacturing-sector/. Accessed $31^{\text {st }}$ August, 2020.

Azumah, S. B., Donkoh, S. A., and Ansah, I. G. K. (2017). Contract farming and the adoption of climate change coping and adaptation strategies in the northern region of Ghana. Environment, Development and Sustainability, 19(6), 2275-2295.

Bryson, J. M. (2018). Strategic planning for public and non-profit organizations: A guide to strengthening and sustaining organizational achievement. John Wiley and Sons: Hoboken, New Jersey, 493 pp.

Dhakshana, A., and Rajandran, K. V. R. (2018). Challenges and Problems on Farmers' Access to Agricultural Credit Facilities in Cauvery Delta, Thanjavur District. St. Theresa Journal of Humanities and Social Sciences, 4(1), 50-62.

Dong, B., Sivakumar, K., Evans, K. R., and Zou, S. (2015). Effect of customer participation on service outcomes: the moderating role of participation readiness. Journal of Service Research, 18(2), 160-176.

Fadairo O. Olajuyigbe, S., Osayomi, T., Adelakun, O., Olaniyan, O., Olutegbe, N. and Adeleke, O. (2020). Climate change, rural livelihoods and ecosystem nexus: Forest communities in agro-ecological zones of Nigeria. In: Leal Filho W., Ogugu N., Adelake L., Ayal D., da Silva I. (eds) African Handbook of Climate Change Adaptation. Springer, Cham. https://doi.org/10.1007/978-3-030-42091-8 155-1

Fadairo, O., Williams, P. A., and Nalwanga, F. S. (2019). Perceived livelihood impacts and adaptation of vegetable farmers to climate variability and change in selected sites from Ghana, Uganda and Nigeria. Environment, Development and Sustainability, 21 (1), 1-19.

Ferraro, V., Piccirillo, C., Tomlins, K., and Pintado, M. E. (2016). Cassava (Manihot esculenta Crantz) and yam (Dioscorea spp.) crops and their derived foodstuffs: safety, security and nutritional value. Critical Reviews in Food Science and Nutrition, 56 (16), 2714-2727.

Forsythe, L., Posthumus, H., and Martin, A. (2016). A crop of one's own? Women's experiences of cassava commercialization in Nigeria and Malawi. Journal of Gender, Agriculture and Food Security, 1(2), 110-128.

Lamboll, R., Nelson, V., Posthumus, H., Martin, A., Adebayo, K., Alacho, F., and Abayomi, L. (2015). Practical lessons on scaling up smallholder-inclusive and sustainable cassava value chains in Africa. Food Chain, 5(1-2): 28-52.

Ogunyinka, O., Guwelamgomba, V., Kaitira, L., Oguntuase, A., Otim, D., and Otim, K. (2018). Transforming rural livelihoods through cassava value addition, a case study of Cassava Adding Value for Africa Project (C: AVA). African Journal of Food, Agriculture, Nutrition and Development, 18(2), 1-12. 
Creative Commons User License: CC BY-NC-ND

Abstracted by: EBSCOhost, Electronic Journals Service (EJS),

Google Scholar, Journal Seek, Scientific Commons,

Food and Agricultural Organization (FAO), CABI and Scopus
Journal of Agricultural Extension

Vol. 24 (4) October, 2020

ISSN(e): 24086851; ISSN(Print); 1119944X

http://journal.aesonnigeria.org

http://www.ajol.info/index.php/iae

Email: editorinchief@aesonnigeria.org

Ohimain, E. I. (2015). A decade (2002-2012) of presidential intervention on cassava in Nigeria; the successes and challenges. Asian Journal of Agricultural Extension, Economics and Sociology, 6(4), 185-193.

Otekunrin, O. A., and Sawicka, B. (2019). Cassava, a 21st Century Staple Crop: How can Nigeria Harness Its Enormous Trade Potentials? Acta Scientific Agriculture, 3(8), 194-202.

Psaltry Internatioal Limited [PIL] (2020). About Psaltry. Available at: https://psaltryinternational.com/about-us/ . Accessed 31 ${ }^{\text {st }}$ August, 2020.

Rahman, S., and Awerije, B. O. (2015). Technical and scale efficiency of cassava production system in Delta State, Nigeria: an application of two-stage DEA approach. Journal of Agriculture and Rural Development in the Tropics and Subtropics (JARTS), 116(1): 59-69.

Saediman, H., Aisa, S., Zani, M., Limi, M. A., and Yusria, W. O. (2019). Food security status of households in a cassava-growing village in Southeast Sulawesi, Indonesia. Journal of Agricultural Extension, 23(1), 199-209.

Schauer, J. (2015). The elephant problem: science, bureaucracy, and Kenya's National Parks, 1955 to 1975. African Studies Review, 58(1), 177-198.

Shackelford, G. E., Haddaway, N. R., Usieta, H. O., Pypers, P., Petrovan, S. O., and Sutherland, W. J. (2018). Cassava farming practices and their agricultural and environmental impacts: a systematic map protocol. Environmental Evidence, 7(1): 30.

Sibanda, N. (2019). Effects of bureaucratic organisational structure on service delivery in the civil service: the case of the Ministry of Transport. Available at: http://localhost:8080/xmlui/handle/123456789/10931. Accessed 29th September, 2020.

Spore Magazine (2017). Nigeria: Inclusive cassava business grows from strength to strength. November $13 . \quad$ Available at: https://medium.com/@Spore Magazine 54746/nigeria-inclusive-cassava-businessgrows-from-strength-to-strength-4ea5ba717f51. Accessed 30 ${ }^{\text {th }}$ August, 2020.

Tafon, R., and Saunders, F. P. (2015). Power relations and cassava: Conservation and development in Cameroon. The Journal of Environment and Development, 24(1), 82104.

Van der Velden, I., Isenberg, B., Ugwu, C., Hanssens, N., Saab, W. and Speelman, L. (2018). Service Delivery Model (SDM: Case Report Psaltry International Ltd. Available at: https://www.idhsustainabletrade.com/uploaded/2018/09/180601-CaseReport-Psaltry-SHORT.pdf. Accessed 29th September, 2020.

Wekesah, F. M., Mutua, E. N., and Izugbara, C. O. (2019). Gender and conservation agriculture in sub-Saharan Africa: a systematic review. International Journal of Agricultural Sustainability, 17(1), 78-91.

Worku, A. A. (2019). Factors affecting diffusion and adoption of agricultural innovations among farmers in Ethiopia case study of Ormia Regional State Western Sewa. Journal of Medical Biology, 1(2), 54-66. 
Creative Commons User License: CC BY-NC-ND

Abstracted by: EBSCOhost, Electronic Journals Service (EJS),

Google Scholar, Journal Seek, Scientific Commons,

Food and Agricultural Organization (FAO), CABI and Scopus

http://eoi.citefactor.org/10.11226/v24i4
Journal of Agricultural Extension

Vol. 24 (4) October, 2020

ISSN(e): 24086851; ISSN(Print); 1119944X

http://journal.aesonnigeria.org

http://www.ajol.info/index.php/jae

Email: editorinchief@aesonnigeria.org

Wuepper, D., Sauer, J., and Kleemann, L. (2018). Sustainable intensification amongst Ghana's pineapple farmers: the complexity of an innovation determines the effectiveness of its training. Environment and Development Economics, 23(1), 98119.

Zabel, F., Delzeit, R., Schneider, J. M., Seppelt, R., Mauser, W., and Václavík, T. (2019). Global impacts of future cropland expansion and intensification on agricultural markets and biodiversity. Nature Communications, 10(1), 1-10. 